\title{
Evaluation of a clay-based acidic bedding conditioner for dairy cattle bedding
}

\author{
R. L. Proietto, ${ }^{*}$ L. S. Hinckley, $†$ L. K. Fox, $\ddagger$ and S. M. Andrew*1 \\ *Department of Animal Science, and \\ †Connecticut Veterinary Diagnostic Laboratory, University of Connecticut, Storrs 06269 \\ ‡Department of Veterinary Clinical Medicine, Washington State University, Pullman 99164
}

\begin{abstract}
This study investigated the effects of a clay-based acidic bedding conditioner on sawdust bedding $\mathrm{pH}$, dry matter (DM), environmental pathogen counts, and environmental bacterial counts on teat ends of lactating dairy cows. Sixteen lactating Holstein cows were paired based on parity, days in milk, milk yield, and milk somatic cell count, and were negative for the presence of an intramammary pathogen. Within each pair, cows were randomly assigned to 1 of 2 treatments with 3 -wk periods in a crossover design. Treatment groups consisted of 9 freestalls per group bedded with either untreated sawdust or sawdust with a clay-based acidic bedding conditioner, added at 3- to 4-d intervals over each 21-d period. Bedding and teat ends were aseptically sampled on d $0,1,2,7,14$, and 21 for determination of environmental bacterial counts. At the same time points, bedding was sampled for $\mathrm{DM}$ and $\mathrm{pH}$ determination. The bacteria identified in the bedding material were total gram-negative bacteria, Streptococcus spp., and coliform bacteria. The bacteria identified on the teat ends were Streptococcus spp., coliform bacteria, and Klebsiella spp. Teat end score, milk somatic cell count, and intramammary pathogen presence were measured weekly. Bedding and teat cleanliness, environmental high and low temperatures, and dew point data were collected daily. The bedding conditioner reduced the $\mathrm{pH}$, but not the $\mathrm{DM}$, of the sawdust bedding compared with untreated sawdust. Overall environmental bacterial counts in bedding were lower for treated sawdust. Total bacterial counts in bedding and on teat ends increased with time over both periods. Compared with untreated sawdust, the treated bedding had lower counts of total gram-negative bacteria and streptococci, but not coliform counts. Teat end bacterial counts were lower for cows bedded on treated sawdust for streptococci, coliforms, and Klebsiella spp. compared with cows bedded on untreated sawdust. The clay-based acidic bedding conditioner reduced environ-
\end{abstract}

Received August 1, 2012.

Accepted November 2, 2012.

${ }^{1}$ Corresponding author: sheila.andrew@uconn.edu mental pathogens in sawdust bedding and teat ends without affecting teat end integrity.

Key words: bedding conditioner, sawdust, teat integrity

\section{INTRODUCTION}

Mastitis is the most prevalent disease affecting dairy cows. The estimated cost of mastitis to the dairy industry exceeds $\$ 2$ billion per year (Schrick et al., 2001). Intramammary (IMM) pathogens causing mastitis can be transferred from other infected cows (contagious pathogens) or enter the mammary gland from environmental sources. Implementation of recommended milking procedures have resulted in a reduction in mastitis due to contagious pathogens; therefore, environmental organisms have increased in importance and are the focus of mastitis control programs for today's dairy industry (Hillerton and Berry, 2003). Environmental organisms are difficult to control because of the close proximity to udders and the ability of organic bedding to support bacterial growth (Hogan and Smith, 1997). Therefore, the type and quality of bedding is an important component of an effective mastitis control program. Sawdust is an organic bedding material that is widely used in confinement housing because of its regional availability and compatibility with manure handling systems (Zdanowicz et al., 2004). However, sawdust bedding increases in moisture and manure content with animal use and, in combination with an increase in sawdust $\mathrm{pH}$ to neutral levels, can promote growth of environmental organisms (Zehner et al., 1986).

Studies have shown a positive correlation between the number of mastitis pathogens in bedding and on teat ends of lactating dairy cows (Rendos et al., 1975; Hogan et al., 1989, 1990, 1999; Hogan and Smith, 1997; Zdanowicz et al., 2004). In addition, the risk for developing an IMI is highly associated with the number of mastitis pathogens found on the teat ends of dairy cows (Schreiner and Ruegg, 2003). Therefore, reducing the number of pathogenic bacteria in bedding reduces the risk of IMI due to environmental organisms.

Bedding conditioners have been used to maintain either alkaline or acidic conditions in bedding and reduce 
growth of environmental bacteria (Hogan et al., 1999). The optimum $\mathrm{pH}$ range for growth of many environmental bacteria is 4.4 to 8.7 (Beales, 2003), although Klebsiella spp. can survive in vitro at pH 3 (O'May et al., 2005). Bedding conditioners have reduced mastitis pathogens in bedding for up to $48 \mathrm{~h}$; however, bacterial loads are more effectively reduced when using acidic bedding additives compared with alkaline conditioners (Hogan et al., 1999).

The teat orifice of the dairy cow is the first line of defense against an invading pathogen (Sordillo et al., 1997); as teat integrity declines, the risk of an IMI increases (Neijenhuis et al., 2000; Zadoks et al., 2001). Hogan et al. (1999) reported that alkaline and acidic bedding additives did not affect teat integrity based on visual observation. However, the effects of the bedding conditioner on teat condition were not documented in that study. Studies on the extent and duration of the effect of bedding conditioners on teat end bacterial counts and teat skin integrity have been limited.

Therefore, the objectives of the current study were to determine if the addition of an acidic clay-based bedding conditioner to sawdust decreased the moisture and $\mathrm{pH}$ of the sawdust bedding and reduced environmental pathogen counts in bedding and on teat ends of lactating dairy cows over $21 \mathrm{~d}$ without affecting teat integrity in mid-lactation Holstein cows.

\section{MATERIALS AND METHODS}

The experiment was conducted at the University of Connecticut Kellogg Dairy Center from August 7 to August 28, 2006, for period 1, and from September 11 to October 2, 2006, for period 2. The animals were cared for according to the protocols of the Institutional Animal Care and Use Committee at the University of Connecticut.

\section{Animals and Housing}

Sixteen lactating Holstein cows were paired based on parity $($ mean $=1.63 \pm 0.5)$, DIM $($ mean $=165 \pm 64.3)$, milk production $($ mean $=43.2 \pm 8.4 \mathrm{~kg} / \mathrm{d}$ ), and $\mathrm{SCC}$ $($ mean $=25,100$ cells $/ \mathrm{mL})$. All animals had previously been housed in freestalls with mattresses and sawdust bedding. In addition, all animals on the study were vaccinated with a commercial vaccine to control coliform mastitis pathogens. Within each pair, cows were randomly assigned to 1 of 2 treatment groups in a 2-period crossover design. Each period consisted of $21 \mathrm{~d}$ of data collection, with $13 \mathrm{~d}$ between periods.

Cows were housed in 2 separate freestall pens (9 stalls per pen) with mattresses covered with heavy canvas and filled with shredded rubber. Each stall was
$213 \mathrm{~cm}$ long and $127 \mathrm{~cm}$ wide and bedded with $10 \mathrm{~cm}$ of sawdust. Sawdust was stored indoors and 2 different batches of sawdust were used during each period. Cows were milked 3 times daily and were fed a corn silagebased TMR. Before the start of each period, stalls were cleaned, washed with a high-pressure hose, and sanitized with a $10 \%$ bleach solution. Treatment groups consisted of stalls with untreated sawdust (control, CON) and stalls with sawdust and the addition of a clay-based acidic bedding conditioner (ABC) containing 45 to $65 \%$ sulfuric acid. The 9 stalls of treatment group CON were bedded with untreated sawdust to a depth of $10 \mathrm{~cm}$. Following the manufacturer's directions, $448 \mathrm{~g}$ of bedding conditioner was applied to the back one-third of each stall for treatment group ABC and sawdust was added to a depth of $10 \mathrm{~cm}$. An additional $140 \mathrm{~g}$ of bedding conditioner was applied to the sawdust in the back one-third of each stall. Visible manure was removed from stalls and alleys 3 times daily during milking. On d 3, 7, 10, 14, and 17 of each period, sawdust was added to both treatment groups to maintain a depth of $10 \mathrm{~cm}$, and $140 \mathrm{~g}$ of bedding conditioner was reapplied to treatment group $\mathrm{ABC}$ at the same time, according to the manufacturer's directions. Daily environmental high and low temperatures and dew points were recorded throughout the study.

\section{Teat Cleanliness}

Teat cleanliness scores were recorded for each cow at each milking throughout the study. Teat cleanliness was scored over a range of 1 to 4 , based on cleanliness of each teat $(1=$ no bedding or manure; $2=$ teat with less than one-fourth of teat surface area observed with any foreign material; $3=$ teat with one-fourth to one-half of teat surface area observed with any foreign material; $4=$ teat with greater than one-half of teat surface area observed with any foreign material). Daily averages were calculated for teat cleanliness for each cow within treatment groups.

\section{Stall Cleanliness}

Stall cleanliness was recorded daily during each milking prior to stall cleaning and scores were averaged by pen and day. The amount of manure in each stall was used as a criterion for cleanliness. A separate 127- $\times$ 127 -cm grid made of PVC pipe and nylon rope to create a $3 \times 3$ arrangement of 9 equal squares was used for each treatment group. The grid was placed in the back half of each stall, and the 9 squares were scored on the basis of visible manure or moisture (adapted from Zdanowicz et al., 2004). The scores ranged from 0 to $5(0=$ clean sawdust; $1=$ small amount of manure 
scattered in square, or less than one-fourth of square; $2=$ manure covering up to approximately one-fourth of square; $3=$ manure covering one-half to less than three-fourths of square; $4=$ manure covering up to three-fourths of square; $5=$ manure covering entire square). Cleanliness scores were averaged over each grid and stall within a pen by day of the study.

\section{Bedding Samples}

Sawdust was aseptically sampled from each of the 4 shipments of bedding before use in the study and analyzed for environmental pathogens as described below. After stalls were bedded with sawdust, bedding samples were collected aseptically on d 0 (immediately after fresh bedding was added to stalls), and at d 1,2, 7, 14, and 21 during the morning milking, as follows. Sterile gloves were used to collect bedding. A $127-\times 127$-cm grid was placed in each stall and bedding was collected from the center of each of the back 6 squares of the grid in order to obtain a composite sample of the back one-third of each stall. Samples were combined for each treatment group and placed into sterile 710-mL Whirl-Pak plastic bags (Nasco Inc., Fort Atkinson, WI). The samples were frozen immediately at $-20^{\circ} \mathrm{C}$. Bedding samples were analyzed for environmental pathogens at Washington State University College of Veterinary Medicine (Pullman). Environmental pathogen counts in bedding were determined using the methods described by Hogan et al. (1989). A bedding sample of $10 \mathrm{~g}$ was added to 90 $\mathrm{mL}$ of sterile PBS in a 500-mL plastic bag and mixed in a stomacher for $40 \mathrm{~s}$. The bag was allowed to rest for 2-3 min. Serial dilutions of the liquid were made and plated onto 3 media: MacConkey agar, thallium crystal violet toxin/ferric citrate (TKT/FC) agar, and blood agar plates. For each of the 3 media, the 3 dilutions plated were $1: 10^{2}, 1: 10^{4}$, and $1: 10^{6}$. Plates were incubated at $37^{\circ} \mathrm{C}$ for $24 \mathrm{~h}$ and were counted (Hogan et al., 1989). MacConkey agar was used for identification of total gram-negative bacteria and coliforms (lactose-positive colonies on MacConkey agar), TKT/FC agar was used for identification of environmental Streptococcus spp., and the blood agar plates were used to determine total bacterial counts.

Bedding samples were collected using the grid system on d 0 (immediately before fresh bedding was added to stalls and before addition of bedding conditioner on $\mathrm{d}$ 14), and at d 1, 2, 7, 14, and 21 during the morning milking for analysis of $\mathrm{pH}$ and DM percentage. Three replicate 25 -g samples of the composite bedding sample were dried at $150^{\circ} \mathrm{C}$ for $24 \mathrm{~h}$ to determine DM percentage (Hogan and Smith, 1997). The $\mathrm{pH}$ of the bedding was determined in duplicate samples by suspending 10 $\mathrm{g}$ of composite bedding from each treatment group in $90 \mathrm{~mL}$ of distilled water (Hogan and Smith, 1997).

\section{Teat Swabs}

Teat swabs were collected from the right front teat of each cow on d $0,1,2,7,14$, and 21 of study. Sterile cotton swabs were dipped in PBS containing $0.1 \%$ sodium thiosulfate (quench solution). Teat ends were sampled as soon as cows entered the parlor without wiping teats. The dipped swab was then rotated 3 times across the exterior of the teat orifice at a $90^{\circ}$ angle. The swabs were then cut into $4 \mathrm{~mL}$ of quench solution with sterile scissors and placed on ice until analysis (Rendos et al., 1975). The swabs were plated within $2 \mathrm{~h}$ of collection at the University of Connecticut Veterinary Medical Diagnostic Laboratory (Storrs). Tubes containing swabs and quench solution were shaken for $60 \mathrm{~s}$ and micropipetted onto agar plates. Bacterial populations were determined using 3 media for environmental organisms. MacConkey agar (Beckman Dickinson Microbiology Systems, Cockeysville, MD) was used for growth of coliform pathogens and diluted 1:3 and 1:10. The TKT/FC agar was used for growth of Streptococcus spp.; TKT/FC plates were diluted to $10^{1}, 10^{2}$, and $10^{3}$ dilutions (Hogan and Smith, 1997). MacConkey-inositol-carbenicillin agar (MCIC) was made as described by Bagley and Seidler (1978). Forty grams of MacConkey agar base was suspended in $1 \mathrm{~L}$ of distilled water with $10 \mathrm{mg}$ of inositol, and 75 mg of carbenicillin was added to the solution within $24 \mathrm{~h}$ of use of plates (Bagley and Seidler, 1978). The MCIC plates are specific for Klebsiella spp. and used 1:3 and 1:10 dilutions; a full agar plate was used for each dilution. In addition, a 1:1 dilution of each sample was plated on blood agar to analyze the samples for pathogens to determine if the selected media were correctly identifying all of the pathogens present in the sample. All plates were incubated for $24 \mathrm{~h}$ at $37^{\circ} \mathrm{C}$, and bacterial colonies were counted. Plates were counted within a range of 1 to 300. Any plates with counts $>300$ were designated too numerous to count and denoted as 400 colonies for statistical analysis.

\section{Milk Sampling}

Milk samples were collected on d 0, 3, 7, 14, and 21 of each period for analysis of SCC. One sample was collected from the right front quarter and another sample was collected from a composite of all 4 quarters. Samples were collected from foremilk subsequent to the removal of 5 streams of milk (Andrew, 2001). Tubes were immediately refrigerated at $5^{\circ} \mathrm{C}$ after collection 
until they were analyzed for SCC by a DeLaval portable DCC Quantitative Cell Analyzer (DeLaval Inc., Kansas City, MO).

Duplicate milk samples were collected from each quarter aseptically on $\mathrm{d}-4,10$, and 17 for period 1 , and $\mathrm{d}-4,3,10$, and 17 for period 2 following the National Mastitis Council (1990) protocol and analyzed for mastitis pathogens by the University of Connecticut Veterinary Medical Diagnostic Laboratory (Andrew, 2001). Milk samples were analyzed for Staphylococcus spp., Staphylococcus aureus, Streptococcus uberis, Streptococcus dysgalactiae, Streptococcus agalactiae, and coliforms (Klebsiella spp. and Escherichia coli). A quarter was defined as having the IMM pathogen present if the pathogen in milk was detected in the second streaking after incubation in both duplicate samples.

\section{Teat End Callosity}

Teat end callosities were recorded on d $0,7,14$, and 21 of each period. Teats were scored based on callosity and ring size of the teat end (Neijenhuis et al., 2000), converted to a binomial variable, and defined as smooth or rough callosity.

\section{Statistical Analysis}

Variables were evaluated for normality. Bacterial counts and SCC data were $\log _{10}$ transformed, and the transformed SCC were termed SCS. Pearson correlation coefficients were computed to estimate associations among bacterial counts in bedding, bacterial counts on teat ends, bedding cleanliness, teat cleanliness, SCS, environmental temperature, and dew point by week and treatment. Paired $t$-tests were used within day by treatment, and $\chi^{2}$ estimates over time within treatment were determined for bedding data and environmental temperature data, and means and standard errors are reported. The mixed model of SAS was used to test treatment effects for all cow-based variables, with day as the repeated measure. Fixed effects included period, treatment (bedding type) and day, and first-order interactions of treatment by day and treatment by period, and the second-order interaction of treatment by period by day. Cow within day was treated as a random effect. Recovery of bacteria from the teat end was recorded as a dichotomous variable, present or absent. Bacterial isolates were classified by group: coliforms, streptococci, and Klebsiella. The frequency of isolation of bacteria by pathogen group was also assessed.

Effect of treatment and associations among presence of bacteria and other variables were tested using the GENMOD procedure (SAS Institute, 2002) with day as the repeated measure, and a compound symmetry correlation structure was used. Frequencies were computed for teat end callosity, and $\chi^{2}$ analysis was performed to test for treatment differences. Differences were determined significant if $P<0.05$.

\section{RESULTS}

All cows completed the study and were free from clinical mastitis and other diseases throughout the study periods. The IMM pathogens isolated during the study are shown in Table 1. Milk SCS were not elevated during the study and all IMM pathogens were considered minor. During period 1 in treatment ABC, staphylococci were identified in 3 quarters of the same cow for each week for both periods, regardless of treatment.

\section{Initial Bedding Bacterial Counts}

Mastitis environmental pathogen bacterial contamination of sawdust bedding was not detected in samples of the shipments of sawdust from all sources throughout the study.

Total Bacterial Counts. Total gram-negative bacterial counts in sawdust increased for both CON and $\mathrm{ABC}$ as the study progressed and we observed no effect of period (Figure 1a). At d 1 and 2, total gram-negative bacterial counts were less for the treated sawdust $(\mathrm{ABC})$ compared with the untreated sawdust $(\mathrm{CON})$.

Table 1. Number of mammary quarters identified with mastitis pathogens for lactating Holstein cows bedded on untreated sawdust (CON) or on sawdust treated with a clay-based acidic bedding conditioner $(\mathrm{ABC})$ in periods 1 and $2(n=8$ cows per treatment)

\begin{tabular}{|c|c|c|c|c|c|c|c|c|c|c|c|c|c|c|}
\hline \multirow[b]{3}{*}{ Pathogen } & \multicolumn{6}{|c|}{ Period 1} & \multicolumn{8}{|c|}{ Period 2} \\
\hline & \multicolumn{3}{|c|}{$\mathrm{CON}$} & \multicolumn{3}{|c|}{$\mathrm{ABC}$} & \multicolumn{4}{|c|}{$\mathrm{CON}$} & \multicolumn{4}{|c|}{$\mathrm{ABC}$} \\
\hline & -4 & 10 & 17 & -4 & 10 & 17 & -4 & 3 & 10 & 17 & -4 & 3 & 10 & 17 \\
\hline Staphylococcus spp. & 4 & 3 & 3 & 2 & 3 & 1 & 1 & 3 & 4 & 1 & 3 & 3 & 3 & 3 \\
\hline Coliforms & 0 & 0 & 1 & 0 & 1 & 2 & 0 & 2 & 0 & 0 & 0 & 0 & 1 & 0 \\
\hline Streptococcus dysgalactiae & 0 & 0 & 0 & 0 & 1 & 0 & 0 & 3 & 1 & 0 & 0 & 0 & 2 & 0 \\
\hline Klebsiella spp. & 0 & 3 & 2 & 0 & 0 & 3 & 0 & 1 & 0 & 0 & 0 & 0 & 0 & 0 \\
\hline
\end{tabular}




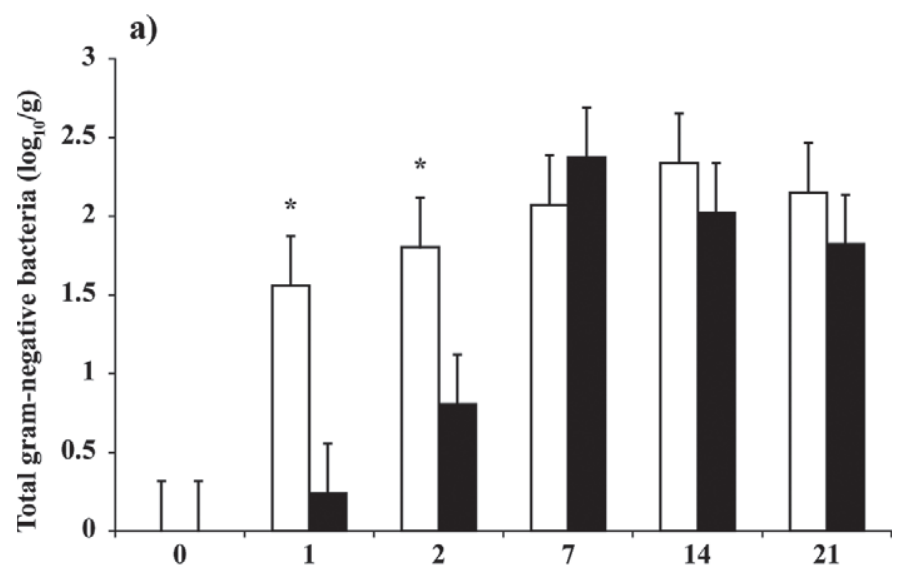

b)

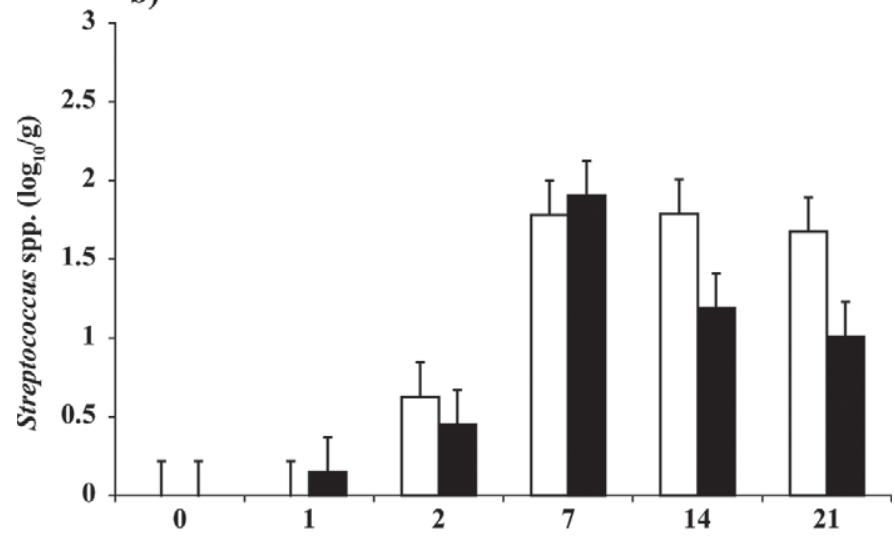

c)

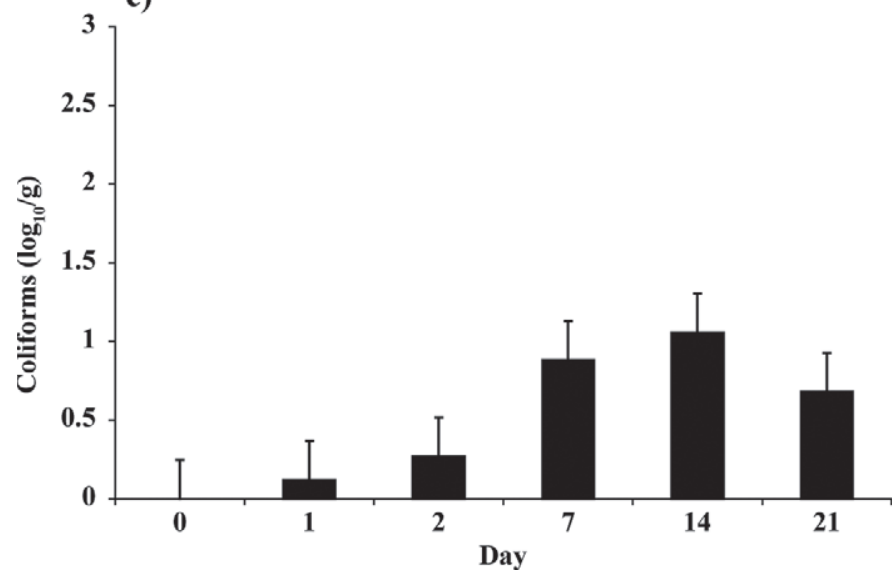

Figure 1. Least squares means and standard errors for (a) total gram-negative bacteria, (b) environmental streptococci, and (c) coliform bacteria isolated from untreated sawdust (CON; white bars) or sawdust treated with a clay-based acidic bedding conditioner (ABC; black bars). Measurements were taken at d $0,1,2,7,14$, and 21 over 2 periods. $* P<0.05$.

Total bacterial counts in the sawdust bedding remained elevated for both treatments at d 7, 14, and 21 .

Environmental Streptococcal Counts. Environmental streptococcal counts in sawdust increased for both $\mathrm{CON}$ and $\mathrm{ABC}$ as the study progressed and we observed no effect of period (Figure 1b). Overall, environmental streptococci increased by $1.85 \log$ on d 7 compared with d $0(P<0.001)$. Environmental streptococcal counts in the sawdust bedding remained increased on d 7, 14, and 21 in both periods. Counts were lower in the bedding of treatment $\mathrm{ABC}$ compared with treatment CON $(P=0.053)$ over both periods.

Coliform Counts. We observed no treatment or period effect for coliform counts in sawdust bedding, although coliform counts increased with time. Coliform counts in sawdust were $0.882 \log$ greater on $\mathrm{d} 7 \mathrm{com}$ pared with d $0(P=0.022$; Figure 1c). Coliform counts in the sawdust remained elevated at d 7, 14, and 21 of both periods.

\section{$D M, p H$, and Cleanliness of Sawdust}

We found a treatment by period by day interaction for $\mathrm{pH}$ of the sawdust $(P<0.001)$. The initial $\mathrm{pH}$ of the sawdust bedding was lower for $\mathrm{ABC}(\mathrm{pH}=1.71)$ than for $\mathrm{CON}(\mathrm{pH}=4.97)$ during period 1 , and lower for $\mathrm{ABC}(\mathrm{pH}=1.88)$ than for $\mathrm{CON}(\mathrm{pH}=5.31)$ during period 2 (Figure 2). The $\mathrm{pH}$ of the sawdust increased to neutral $\mathrm{pH}$ by $\mathrm{d} 1$ for $\mathrm{CON}$ and by d 14 for $\mathrm{ABC}$ during period 1 . During period 2 , the $\mathrm{pH}$ of bedding for CON increased from a pH of 5.3 to neutral $\mathrm{pH}$ by $\mathrm{d} 2$, and for $\mathrm{ABC}$ increased from $\mathrm{pH} 1.9$ to 5.5 by d 21, but did not reach neutrality. The $\mathrm{pH}$ of bedding was lower for treatment $\mathrm{ABC}$ at all sampling times during period $2(P<0.05)$

The DM of the sawdust was similar for all batches (89.3\%). There was a 9.8 percentage unit decrease from d 0 to d 1 during period 1 for both $\mathrm{ABC}$ and $\mathrm{CON}$, with no effect of treatment (data not shown). The cleanliness of sawdust bedding differed by period $(P=$ $0.004)$ and by week $(P<0.001$; Figure 3$)$. Overall, the amount of manure in stalls was greater during period 2 than during period 1 and was greater in wk 4 of each period. The manure in the stalls did not differ between treatments throughout the study.

\section{Teat Swab Counts of Cows}

Environmental Streptococcal Counts. Environmental streptococcal counts on teat ends were not affected by treatment during period 1 (Figure 4a). However, during period 2, we observed fewer environmental streptococci on the teat ends of dairy cows in $\mathrm{ABC}$ than in CON at d 1, 7, and $14(P<0.001$; Figure $4 \mathrm{~b})$. Environmental streptococcal counts increased by d 14 of period 1 and by d 7 of period 2. When categorized by presence or absence of a pathogen, the number of cows identified with streptococci on the teat ends was 

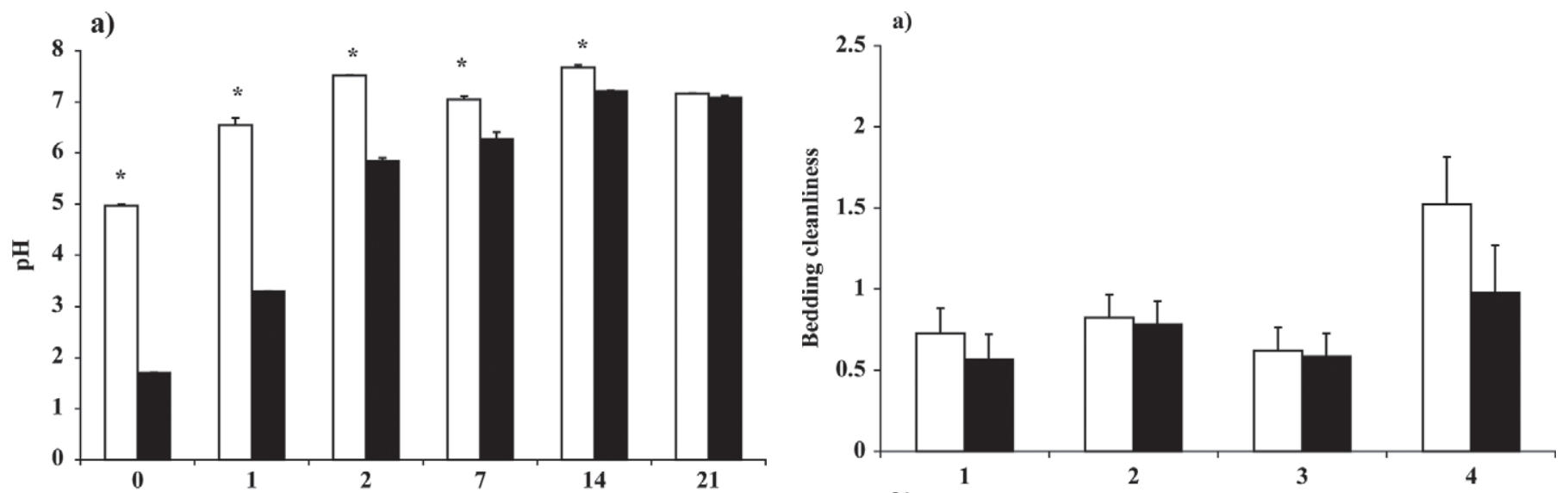

b)
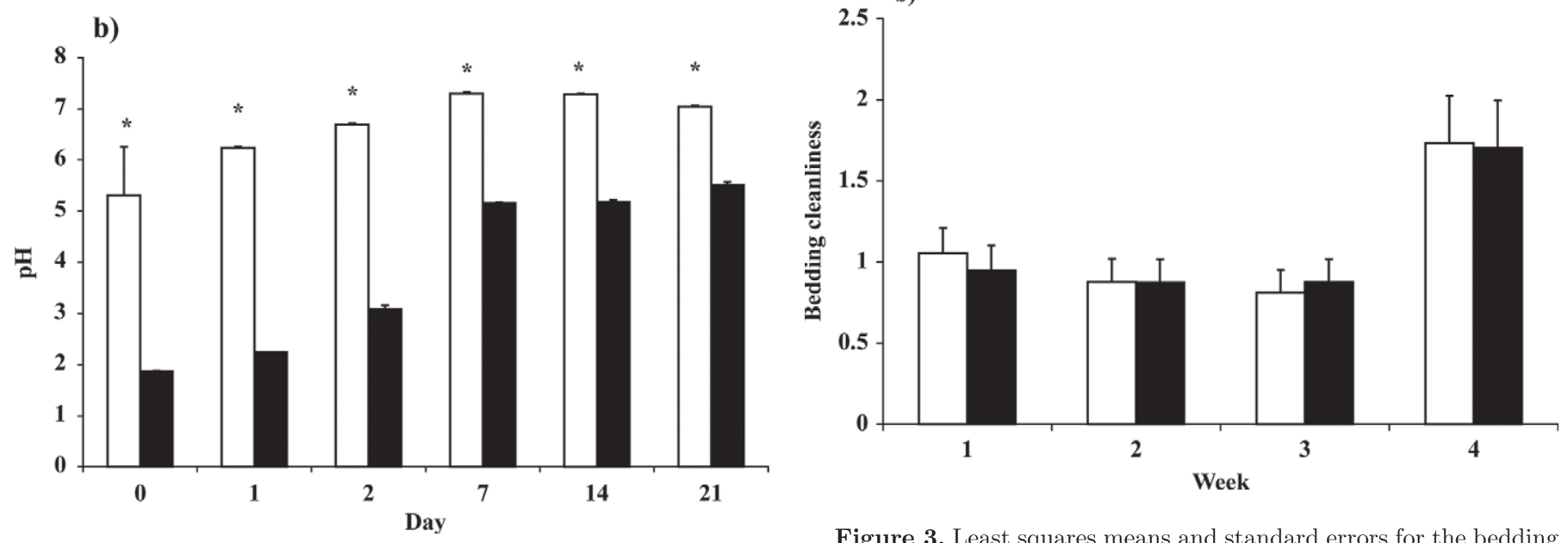

Figure 2. Least squares means and standard errors for the $\mathrm{pH}$ of untreated sawdust (CON; white bars) or sawdust treated with a claybased acidic bedding conditioner (ABC; black bars). Measurements were taken at $\mathrm{d} 0,1,2,7,14$, and 21 during (a) period 1 and (b) period 2. ${ }^{*} P<0.05$

lower for ABC compared with $\mathrm{CON}(P=0.008$; data not shown). Fewer cows were identified with streptococci on the teat ends for $\mathrm{ABC}$ than for $\mathrm{CON}$ on $\mathrm{d}$ $0,1,2,7$, and 14 during period $2(P<0.001$; data not shown), and the magnitude of treatment effect was greater during period 2. We observed significant correlations among increased streptococci on the teat ends, increased streptococci in the bedding $(P=0.001)$, and decreased bedding DM $(P=0.004)$.

Coliform Counts. We found a significant treatment by day by period interaction for coliform counts on teat ends $(P<0.001)$. Coliform counts on the teat ends were lower for ABC compared with $\mathrm{CON}$ on d 14 during period 1 ( $P=0.002$; Figure $5 \mathrm{a})$. However, during period 2, coliform counts were lower for $\mathrm{ABC}$ on $\mathrm{d}$ 7 and $14(P<0.011)$ compared with CON (Figure 5b). Coliform counts on teat ends were lower for ABC during period 2 than during period 1 . When categorized by presence or absence or a pathogen, the frequency of

Figure 3. Least squares means and standard errors for the bedding cleanliness of untreated sawdust (CON; white bars) or sawdust treated with a clay-based acidic bedding conditioner (ABC; black bars). Measurements were taken 3 times daily during (a) period 1 and (b) period 2. Cleanliness scores were on a 0 to 5 scale, where $0=$ clean, 5 $=$ extremely soiled.

cows identified with coliform bacteria was less for cows in the $\mathrm{ABC}$ group compared with cows in the CON group $(P=0.002)$. We observed a treatment by period effect, with fewer cows identified with streptococci on the teat ends for ABC than CON during period $2(P$ $=0.001$; data not shown); the magnitude of treatment effect was greater during this period and was similar to the bacterial count data for coliforms. The risk for coliforms on the teat ends increased with increased counts of coliforms in the bedding $(P<0.001)$ and an increase in $\mathrm{pH}$ of the sawdust bedding $(P=0.039)$.

Klebsiella Counts. Teat end Klebsiella spp. were not detected or counts were lower than 0.5 log throughout the study, except on d 14 of period 1 and on d 14 and 21 of period 2 for CON, when Klebsiella spp. counts were greater than $1 \log$ and significantly differed from that of $\mathrm{ABC}$ at these time points(Figure 6). When cows were categorized by the presence or absence of a pathogen, the frequency of cows with Klebsiella on the 
a)

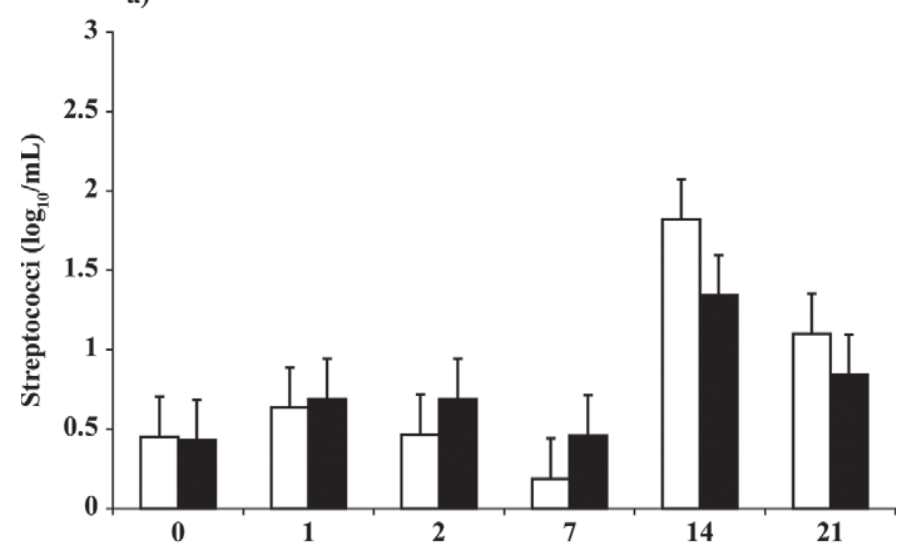

b)

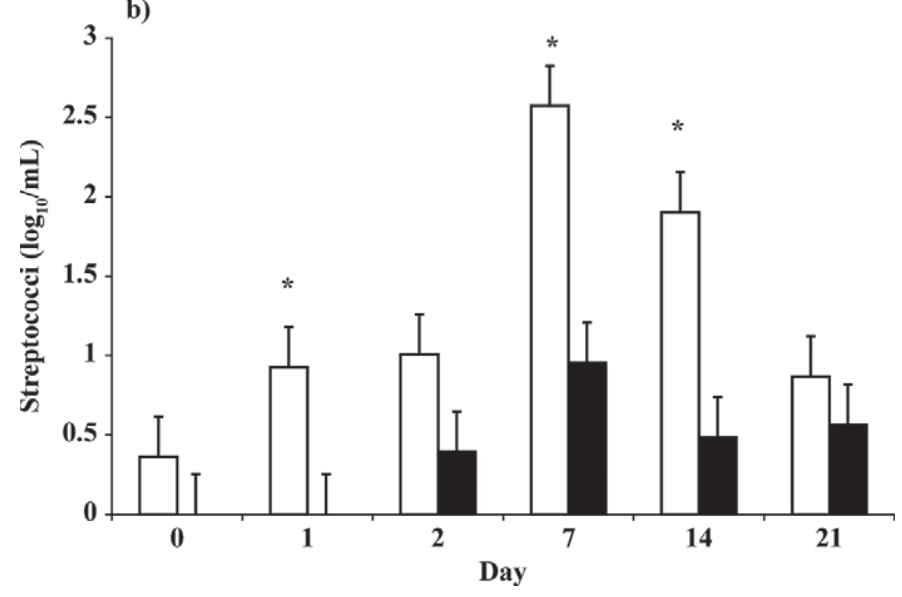

Figure 4. Least squares means and standard errors for streptococci isolated from teat-end swabs of 16 lactating Holstein cows bedded on untreated sawdust (CON; white bars) or sawdust treated with a claybased acidic bedding conditioner (ABC; black bars). Measurements were taken at d $0,1,2,7,14$, and 21 during (a) period 1 and (b) period 2. ${ }^{*} P<0.05$.

teat ends was less in $\mathrm{ABC}$ than in $\mathrm{CON}(P=0.045$; Figure 6). Fewer cows were identified with Klebsiella spp. on the teat ends in $\mathrm{ABC}$ than in $\mathrm{CON}$ for all days sampled during period $2(P=0.002$; data not shown), with the exception of d 0 , when Klebsiella spp. were not isolated on teat ends. Risk for Klebsiella spp. on teat ends increased with increased counts of coliforms in the bedding $(P<0.001)$.

\section{Milk SCS, Teat End Cleanliness, and Teat End Callosity}

The composite SCS and the SCS for the right front quarter did not differ by treatment, period, or day (mean $=1.24 \pm 0.10$ and $1.33 \pm 0.88$, respectively .

Teat end cleanliness did not differ by treatment (mean $=1.14 \pm 0.047)$; however, teat cleanliness score was greater (i.e., teats were dirtier) in period 2 than in

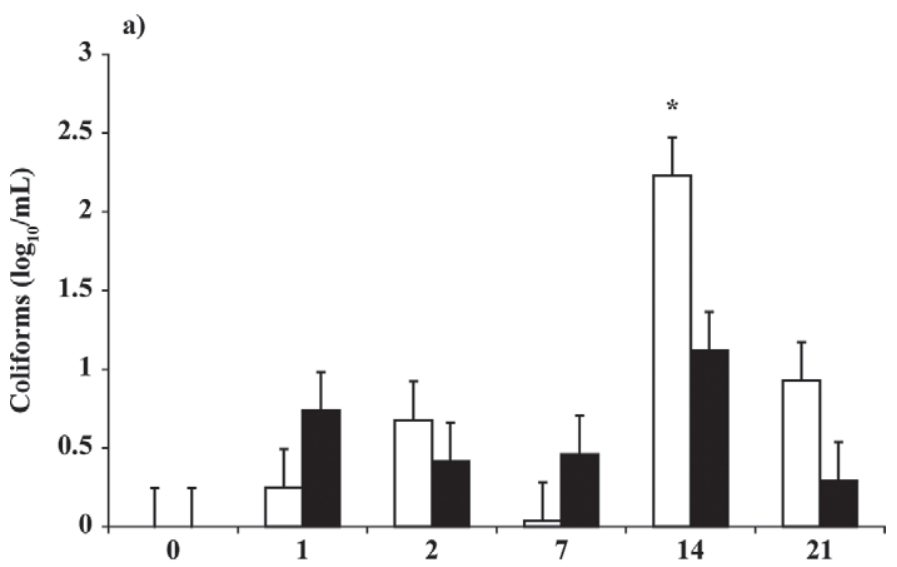

b)

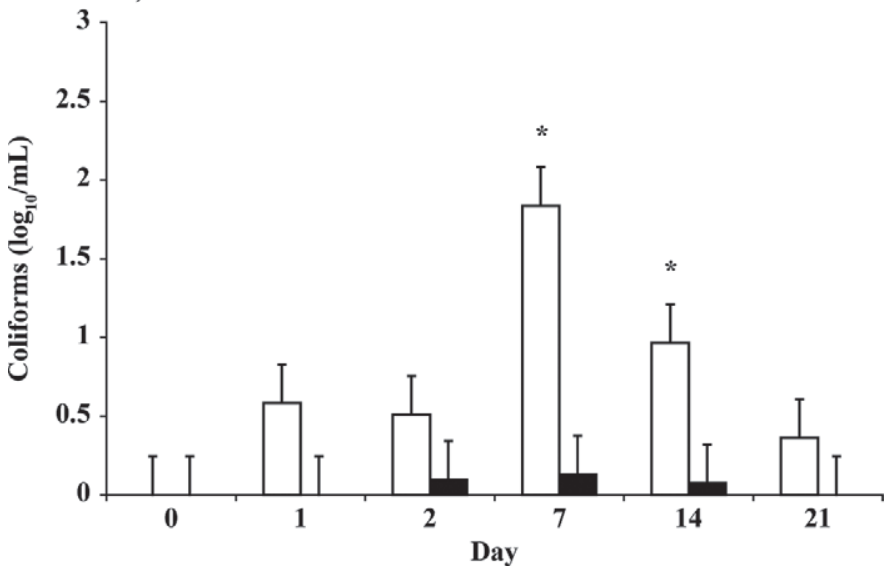

Figure 5. Least squares means and standard errors for coliform bacteria isolated from teat-end swabs of 16 lactating Holstein cows bedded on untreated sawdust (CON; white bars) or sawdust treated with a clay-based acidic bedding conditioner (ABC; black bars). Measurements were taken at d 0,1, 2, 7, 14, and 21 during (a) period 1 and (b) period 2. ${ }^{*} P<0.05$.

period $1(P<0.001)$. Teat end callosity did not differ by treatment or period.

\section{Environmental Temperature and Dew Point}

Environmental temperatures and dew points were similar among weeks within both periods. The mean high temperature for period $1\left(26.2 \pm 3.3^{\circ} \mathrm{C}\right)$ was higher than that for period $2\left(20.1 \pm 2.2^{\circ} \mathrm{C}\right)$. The mean low temperature for period $2\left(10.2 \pm 1.97{ }^{\circ} \mathrm{C}\right)$ was lower than that for period $1\left(14.5 \pm 1^{\circ} \mathrm{C}\right)$. The mean high dew point for period $2\left(13.8 \pm 1.16{ }^{\circ} \mathrm{C}\right)$ was lower than that for period $1\left(17.2 \pm 0.32^{\circ} \mathrm{C}\right)$.

\section{Pearson Correlations for Bedding and Teats}

The $\mathrm{pH}$ of the sawdust was positively correlated with bacterial counts in the bedding. As the $\mathrm{pH}$ increased towards neutrality, counts of total gram-negative bacteria 


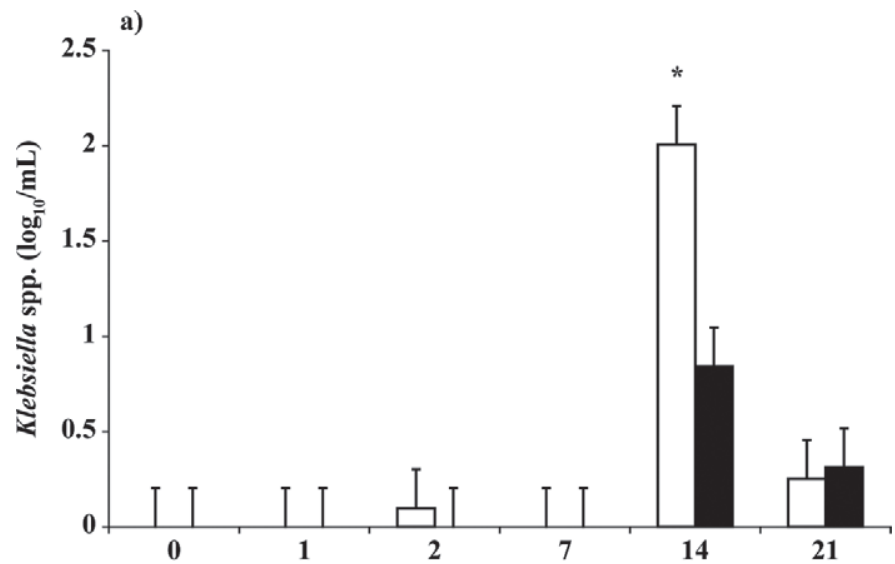

b)

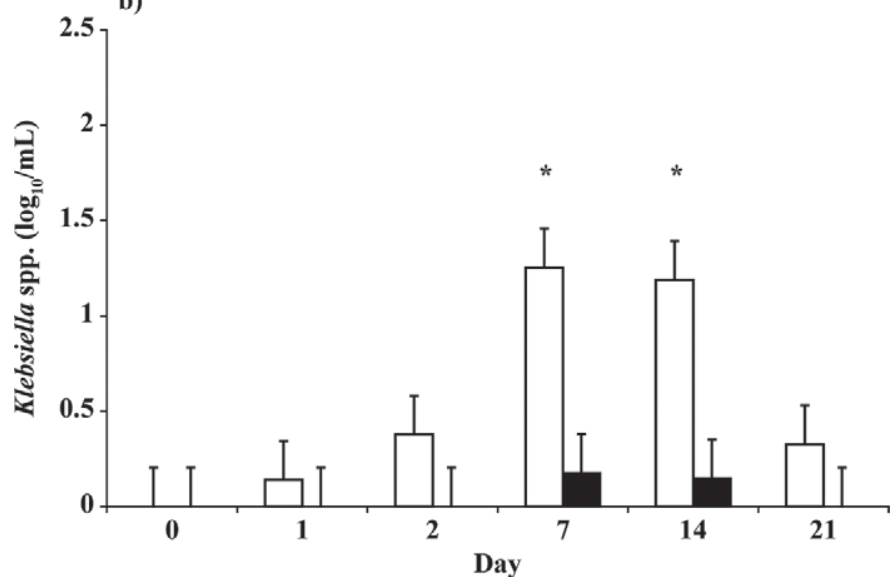

Figure 6. Least squares means and standard errors for Klebsiella spp. isolated from teat-end swabs of 16 lactating Holstein cows bedded on untreated sawdust (CON; white bars) or sawdust treated with a clay-based acidic bedding conditioner (ABC; black bars). Measurements were taken at d $0,1,2,7,14$, and 21 during (a) period 1 and (b) period $2 .{ }^{*} P<0.05$

$(\mathrm{r}=0.88 ; P=0.003)$, coliforms $(\mathrm{r}=0.72 ; P=0.046)$, and streptococci $(\mathrm{r}=0.84 ; P=0.009)$ increased.

Coliform counts in the bedding were correlated with coliform counts on teat ends $(\mathrm{r}=0.78 ; P=0.024)$. During period 2 for treatment $\mathrm{ABC}$, we found a positive correlation between coliforms $(\mathrm{r}=0.95 ; P=0.047)$ and streptococci $(\mathrm{r}=0.97 ; P=0.026)$ isolated in the bedding and on teat ends.

\section{DISCUSSION}

\section{Effect of Treatment on Bedding Pathogens}

All environmental bacterial pathogens increased in bedding by $\mathrm{d} 7$, as expected, due to contamination with manure from the study cows. Hogan et al. (1999, 2007) reported decreases in the $\mathrm{pH}$ of sawdust with addition of a commercial acidic bedding conditioner. The $\mathrm{pH}$ of the treated sawdust was $<2$ on $\mathrm{d} 0$ but reached a neutral $\mathrm{pH}$ by d $6(\mathrm{pH}=7$; Hogan et al., 1999, 2007). In the current experiment, we observed a reduction in $\mathrm{pH}$ of the sawdust for $\mathrm{ABC}$ to $<2$ on $\mathrm{d}$ 0 , and the $\mathrm{pH}$ remained acidic by $\mathrm{d} 7$ of period $2(\mathrm{pH}$ $=5.15)$, when the greatest treatment effects in teat end bacterial counts were observed (Figure 2). The $\mathrm{pH}$ remained below 5.15 for longer than reported in the studies of Hogan et al. (1999, 2007). We determined that when the acidic bedding conditioner was added to sawdust, the $\mathrm{pH}$ remained below 5.15 for at least $77 \mathrm{~h}$ when reapplied according to manufacturer's directions. However, this was only observed during period 2 , when bedding and teat end soil were greater than in period 1 .

As the DM percentage in the bedding decreased and the $\mathrm{pH}$ increased, counts of Klebsiella spp., coliforms, and streptococci increased in the sawdust and on teat ends. Zdanowicz et al. (2004) also reported that the DM percentage in the sawdust was negatively correlated with bedding pathogen counts. In contrast, Hogan and Smith (1997) reported that bacterial counts in bedding decreased when the $\mathrm{pH}$ of the bedding was lower, but the reduction was independent of the DM percentage. In addition, Hogan et al. (2007) reported that the use of an acidic bedding conditioner did not affect DM levels in sawdust. As the moisture of the bedding increased, counts of environmental mastitis pathogens in the bedding in the current study increased because bacteria can utilize moisture and the nutrients of organic bedding material for bacterial growth (Zehner et al., 1986).

\section{Effect of Treatment on Teat End Bacterial Counts}

The bedding conditioner was effective in reducing bacterial counts on teat ends for all 3 environmental bacteria. Significant differences were apparent after d 2 of the study. The magnitude of effects of treatment was greater during period 2 than in period 1 for all environmental bacteria. Hogan et al. (1999) reported a reduction in bacterial load on the teat ends of cows bedded on sawdust with the addition of an acidic bedding additive lasting for $48 \mathrm{~h}$ after treatment (Hogan et al., 1999). Microorganisms have a defined optimum range of external $\mathrm{pH}$ required for growth, and acidification is effective in controlling multiplication (Beales, 2003). The acidic bedding conditioner reduces the $\mathrm{pH}$ of the sawdust, which is the external environment for the bacterial pathogens. The strong acids denature enzymes on the cell surface of the environmental organisms by lowering cytoplasmic $\mathrm{pH}$ due to increased proton permeability, which results in a reduced growth rate (Cheroutre-Vialette et al., 1998). The optimum pH for growth of these environmental organisms is between 4.4 and 8.7; as the $\mathrm{pH}$ decreases below this range, the optimum temperature for growth is increased, result- 
ing in further reduction of the growth rate (Beales, 2003). Goodson and Rowbury (1989) reported that $E$. coli strains held at $\mathrm{pH} 7$ failed to grow after a short exposure to $\mathrm{pH} 3$ to 3.5 .

In the present study, the $\mathrm{pH}$ of the bedding remained below 5.15 during period 2, when the greatest decrease in environmental pathogens on teat ends was observed. This finding indicates that the $\mathrm{pH}$ of the bedding potentially reduces environmental bacterial growth in bedding and on teat ends of cows housed on freestalls with sawdust bedding.

Similar to the results of the current study, several studies have shown positive correlations between counts of environmental streptococci, coliforms, and Klebsiella spp. in bedding with counts on teat ends. As environmental pathogens increase in the bedding, colonization of environmental bacteria increases on teat ends (Rendos et al., 1975; Hogan et al., 1989, 1990, 1999; Hogan and Smith, 1997; Zdanowicz et al., 2004). In addition, as the $\mathrm{pH}$ of the bedding increases and the DM percentage of the bedding decreases, environmental bacteria in the organic bedding material increase (Zehner et al., 1986; Zdanowicz et al., 2004). In agreement, Godden et al. (2008) postulated that bedding with high total carbon content and a high $\mathrm{pH}$ supports the growth of Klebsiella pneumoniae. Zehner et al. (1986) reported that kiln-dried sawdust was not a risk for environmental pathogen growth, but when moisture and manure were present, bacterial growth increased. The increased bacterial counts in the bedding were associated with increased risk of bacterial counts on teat ends and, ultimately, increased risk of IMI (Rendos et al., 1975; Zehner et al., 1986; Hogan et al., 1989, 1990, 1999; Hogan and Smith, 1997; Zdanowicz et al., 2004).

Across periods, increased coliform counts in the bedding were associated with increased $E$. coli and Klebsiella on teat ends. During period 2 in treatment $\mathrm{ABC}$, we observed a similar association between coliform and environmental streptococcal counts in the sawdust and on the teat ends. Hogan and Smith (1997) and Zdanowicz et al. (2004) also reported positive correlations between coliforms and streptococci in sawdust bedding and bacterial counts on teat ends in tie-stall and freestall housing, respectively. These data support the hypothesis that a reduction in bacterial counts in bedding is effective at reducing bacterial counts on teat ends. In addition, environmental pathogens on teat ends of cows were reduced in cows bedded on treated sawdust compared with cows bedded on untreated sawdust only during period 2 , when manure contamination of bedding was greater.

The clay-based acidic bedding conditioner resulted in a sustained reduction in bedding $\mathrm{pH}$ for $14 \mathrm{~d}$ during period 1 and for $21 \mathrm{~d}$ during period 2 compared with untreated sawdust. The total gram-negative bacterial counts in the treated bedding were significantly reduced for $2 \mathrm{~d}$ in both periods. This was similar to the studies of Hogan et al. (1999, 2007), where the acidic bedding conditioner reduced the $\mathrm{pH}$ of the sawdust bedding below neutral for $48 \mathrm{~h}$ and the total gram-negative bacterial counts in bedding were reduced for $2 \mathrm{~d}$. In the current experiment, the acidic bedding conditioner was applied on $\mathrm{d} 0,3,7,10$, and 17 of each period, which most likely resulted in persistency of reduced $\mathrm{pH}$ for the treated bedding, compared with the results of Hogan et al. (1999, 2007).

Somatic cell score did not differ between treatments in the study (Table 1). However, mean milk SCS was 1.40 or lower throughout the study, and bacterial loads in bedding and on teats were low compared with those reported in other studies (Hogan and Smith, 1997; Hogan et al., 1999; Zdanowicz et al., 2004). Hogan et al. (1989) reported a decreased incidence of IMI with a reduction of the bacterial load on the teat ends (Hogan et al., 1989). If a pathogen enters the teat canal and gains entry into the mammary gland, the immune response results in an increase in neutrophils, which is reflected in an increase in SCC (Sordillo et al., 1997).

Teat end callosity did not differ between treatment groups throughout the study. Teat cracks allow penetration of pathogens into the teat canal and are associated with increased risk of mastitis (Neijenhuis et al., 2000, 2001). Hogan et al. (1999) reported no changes in teat skin associated with bedding additives based on general observations; the results of the present study are in agreement. In the current study, $<24 \%$ of teat ends were classified as having rough callosity, which is similar to other reports in lactating dairy cows. Neijenhuis et al. (2000) reported that $24 \%$ of the teats were cracked in a herd of 40 lactating dairy cows observed over a 14 -wk period. Teat end integrity did not differ by treatment in the present study; cows with healthy teat ends were in similar condition to machine-milked lactating cows in other studies (Neijenhuis et al., 2000).

\section{CONCLUSIONS}

Use of the clay-based acidic bedding conditioner was associated with reduced environmental counts of total gram-negative bacteria, streptococci, coliforms, and Klebsiella spp. in bedding and on teat ends. Reductions of environmental streptococci, coliforms, and Klebsiella spp. on the teat ends was attributed to a reduction in $\mathrm{pH}$ of the bedding material. This effect was more pronounced during period 2 when manure contamination of sawdust and teat ends was greater, and the reduced $\mathrm{pH}$ of the treated sawdust bedding persisted for the 21-d period. The integrity of teats was not affected by 
the addition of acidic bedding conditioner. The addition of a clay-based bedding conditioner to sawdust was associated with reduced environmental bacteria on teat ends in the presence of manure when the bedding conditioner was added to sawdust at frequent intervals.

\section{ACKNOWLEDGMENTS}

The authors thank David Schreiber Jr., Gary W. Kazmer, Lawrence K. Silbart, and Christian Proietto (all of University of Connecticut, Storrs) for technical assistance. Appreciation is extended to Mary Margaret Cole, manager of the Kellogg Dairy Center (University of Connecticut, Storrs) for animal care.

\section{REFERENCES}

Andrew, S. M. 2001. Effect of composition of colostrum and transition milk from Holstein heifers on specificity rates of antibiotic residue tests. J. Dairy Sci. 84:100-106.

Bagley, S. T., and R. J. Seidler. 1978. Primary Klebsiella identification with MacConkey-inositol-carbenicillin agar. Appl. Environ. Microbiol. 36:536-538

Beales, N. 2003. Adaptation of microorganisms to cold temperatures, weak acid preservatives, low $\mathrm{pH}$, and osmotic stress: A review. Comp. Rev. Food Sci. Food Safety 3:1-20.

Cheroutre-Vialette, M., I. Lebert, M. Hebraud, J. C. Labadie, and A. Lebert. 1998. Effects of $\mathrm{pH}$ or a stress on growth of Listeria monocytogenes. Int. J. Food Microbiol. 42:71-77.

Godden, S., R. Bey, K. Lorch, R. Farnsworth, and P. Rapnicki. 2008. Ability of organic and inorganic bedding materials to promote growth of environmental bacteria. J. Dairy Sci. 91:151-159.

Goodson, M., and R. J. Rowbury. 1989. Resistance of acid-habituated Escherichia coli to organic acids and its medical and applied significance. Lett. Appl. Microbiol. 8:211-214.

Hillerton, J. E., and E. A. Berry. 2003. The management and treatment of environmental streptococcal mastitis. Vet. Clin. North Am. Food Anim. Pract. 19:157-169.

Hogan, J. S., K. L. Smith, K. H. Hoblet, D. A. Todhunter, P. S. Schoenberger, W. D. Hueston, D. E. Pritchard, G. L. Bowman, L. E. Heider, B. L. Brockett, and H. R. Conrad. 1989. Bacterial counts in bedding materials used on nine commercial dairies. J. Dairy Sci. 72:250-258.

Hogan, J. S., K. L. Smith, D. A. Todhunter, and P. S. Schoenberger. 1990. Bacterial counts associated with recycled newspaper bedding. J. Dairy Sci. 73:1756-1761.

Hogan, J. S., and K. L. Smith. 1997. Bacteria counts in sawdust bedding. J. Dairy Sci. 80:1600-1605.
Hogan, J. S., V. L. Bogacz, L. M. Thompson, S. Romig, P. S. Schoenberger, W. P. Weiss, and K. L. Smith. 1999. Bacterial counts associated with sawdust and recycled manure bedding treated with commercial conditioners. J. Dairy Sci. 82:1690-1695.

Hogan, J. S., S. L. Wolf, and C. S. Petersson-Wolfe. 2007. Bacterial counts in organic materials used as free-stall bedding following treatment with a commercial conditioner. J. Dairy Sci. 90:10581062 .

National Mastitis Council. 1990. Microbiological Procedures for the Diagnosis of Bovine Udder Infection. 3rd ed. National Mastitis Council, Madison, WI.

Neijenhuis, F., H. W. Barkema, H. Hogeveen, and J. P. T. M. Noordhuizen. 2000. Classification and longitudinal examination of callused teat ends in dairy cows. J. Dairy Sci. 83:2795-2804.

Neijenhuis, F., G. A. Mein, J. S. Britt, D. J. Reinermann, J. E. Hillerton, R. Farnsworth, J. R. Baines, T. Hemling, I. Ohnstad, N. Cook, W. F. Morgan, and L. Timms. 2001. Evaluation of bovine teat condition in commercial dairy herds: 4 . Relationship between teat-end callosity or hyperkeratosis and mastitis. Pages 362-366 in Proc. 2nd Int. Symp. Mastitis and Milk Quality. National Mastitis Council, Madison, WI.

O'May, G. A., N. Reynolds, and G. T. Macfarlane. 2005. Effect of $\mathrm{pH}$ on an in vitro model of gastric microbiota in enteral nutrition patients. Appl. Environ. Microbiol. 71:4777-4783.

Rendos, J. J., R. J. Eberhart, and E. M. Kesler. 1975. Microbial populations of teat ends of dairy cows, and bedding materials. J. Dairy Sci. 58:1492-1500.

SAS Institute. 2002. SAS User's Guide: Statistics. Version 9 ed. SAS Institute Inc., Cary, NC.

Schreiner, D. A., and P. L. Ruegg. 2003. Relationship between udder and leg hygiene scores and subclinical mastitis. J. Dairy Sci. $86: 3460-3465$.

Schrick, F. N., M. E. Hockett, A. M. Saxton, M. J. Lewis, H. H. Dowlen, and S. P. Oliver. 2001. Influence of subclinical mastitis during early lactation on reproductive parameters. J. Dairy Sci. 84:1407-1412

Sordillo, L. M., K. Shafer-Weaver, and D. DeRosa. 1997. Immunobiology of the mammary gland. J. Dairy Sci. 80:1851-1865.

Suriyasathaporn, W., Y. H. Schukken, M. Nielen, and A. Brand. 2000. Low somatic cell count: A risk factor for subsequent clinical mastitis in a dairy herd. J. Dairy Sci. 83:1248-1255.

Zadoks, R. N., H. G. Allore, H. W. Barkema, O. C. Sampimon, G. J. Wellenberg, Y. T. Grohn, and Y. H. Schukken. 2001. Cow and quarter level risk factors for Streptococcus uberis and Staphylococcus aureus mastitis. J. Dairy Sci. 84:2649-2663.

Zdanowicz, M., J. A. Shelford, C. B. Tucker, D. M. Weary, and M. A. G. von Keyserlingk. 2004. Bacterial populations on teat ends of dairy cows housed in free stalls and bedded with either sand or sawdust. J. Dairy Sci. 87:1694-1701.

Zehner, M. M., R. J. Farnsworth, R. D. Appleman, K. Larntz, and J. A. Springer. 1986. Growth of environmental mastitis pathogens in various bedding materials. J. Dairy Sci. 69:1932-1941. 